\title{
Analisis Teknis Konversi KM Minajaya 11 Tuna Long Liner Menjadi Kapal Pengangkut Ikan
}

\author{
Irfan Byna Nur Akbar, Taufik Fajar Nugroho, dan Raja Oloan Saut Gurning \\ Departemen Teknik Sistem Perkapalan, Fakultas Teknologi Kelautan, Institut Teknologi Sepuluh Nopember (ITS) \\ e-mail: irfan_byna@yahoo.com
}

\begin{abstract}
Abstrak-Kapal penangkap ikan Minajaya Tuna Long Liner 11 adalah salah satu kapal dari 24 shipset yang dimiliki oleh PT.PANN. Dilatarbelakangi kapal Minajaya yang memiliki 512 GT sehingga tidak dapat beroperasi untuk menangkap ikan karena regulasi dari pemerintah. Sehingga kapal Minajaya 11 akan dikonversi menjadi kapal pengangkut ikan, skenario kapal pengangkut ikan ini adalah berlayar menuju beberapa titik fishing ground pada WPP 716 di Indonesia. Kapal ini akan melayani dan menjual logistic kepada kapal penangkap ikan berukuran 40-50 GT di fishing ground yang berupa bahan bakar, umpan, es, pertukaran ABK kapal dan penyimpanan frozen tuna. Setelah melakukan proses pengaturan, kalkuasi dan desain, kapal pengangkut ikan dimodifikasi dengan menambahkan bunkering system dilengkapi dengan pompa Iron Gear Pumps yang mampu mengisi penuh tangka bahan bakar 1 kapal penangkap ikan berukuran 40-50 GT selama 20 menit. Dimodifikasi juga dengan menambahkan adsorption system sebuah sistem pendingin yang memanfaatkan gas buang main engine kapal Minajaya dan mampu untuk menghasilkan $500 \mathrm{~kg}$ es dalam 1 hari. Loading and Unloading system untuk mengangkut ikan Tuna menggunakan portable conveyor yang disambungkan ship to ship dan diangkut menggunakan provision crane 6 ton. Seluruh desain sistem, konfigurasi, fire and safety plan, rencana umum dari kapal pengangkut ikan dimodifikasi dengan germanischer Lloyd dan SOLAS sebagai acuan untuk memodifikasi yang memenuhi standard. Biaya produksi konversi kapal Minajaya 11 membutuhkan biaya Rp. 2.902.000.000 dengan lama waktu pengerjaan selama 5 bulan dan 6 hari.
\end{abstract}

Kata Kunci-Kapal pengangkut ikan, fishing ground, frozen tuna, bunkering system, adsorption system, loading and unloading system.

\section{PENDAHULUAN}

$\mathrm{M}$ INAJAYA Tuna Long Liner terklasifikasi sebagai sebuah kapal penangkap ikan dan didesain khusus untuk menangkap tuna dan kapal ini dimiliki oleh PT IKI (Industri Kapal Indonesia). Regulasi terbaru dari Kementrian Kelautan dan Perikanan yang dituliskan pada surat No. B.1234/DJTP/P.I410.D4/31/12/2015 mengenai dilarangnya pengoperasian kapal penangkap ikan diatas 150 GT untuk menangkap ikan. Minajaya yang memiliki kapasitas 512 GT tidak dapat dioperasikan dari regulasi yang berlaku. Karena regulasi yang berlaku Minajaya 11 sudah lama tidak dioperasikan dan membutuhkan reparasi untuk mengembalikan fungsi kapal tersebut.

Cara alternatif dapat dilakukan pada Minajaya 11 untuk mendapatkan keuntungan. Kementrian Kelautan dan Perikanan menunjuk PT. Idustri Kapal Indonesia (IKI) untuk mengkonversi minajaya dari kapal penangkap ikan menjadi kapal pengangkut ikan. Minajaya sebagai kapal pengangkut ikan diproyeksi untuk mengangkut tangkapan ikan dari kapal penangkap ikan yang berada pada fishing ground. Kapal pengangkut ikan ini juga akan diproyeksikan sebagai penyuplai logistic yang dibutuhkan kapal penangkap ikan di fishing grounds.

Skenario ini akan diaplikasikan pada kapal Minajaya 11 yang akan menjadi objek pada penelitian ini, dipilih Minajaya nomor 11 karena kelengkapan dokumen, desain dan aransemen terdapat pada kapal Minajaya 11 yang terlektak pada galangan PT.IKI yang terletak pada Makassar, Sulawesi Selatan. Reparasi dan modifikasi sistem akan diperlukan bagi Minajaya 11 untuk mengoptimal operasional Minajaya 11 sebagai kapal pengangkut ikan. Pada penelitian kali ini akan dibahas perubahan-perubahan sistem yang terjadi.

\section{TINJAUAN PUSTAKA}

\section{A. Definisi Kapal Pengangkut Ikan}

Menurut badan hukum no. 45 tahun 2009, chapter V artikel 34 tentang fishery business, kapal ikan didefinisikan sebagai kapal yang menolong atau melakukan proses dari penangkapan ikan dan membantu pengoperasian dari penangkapan ikan itu. Secara umum, kapal ikan dibagi menjadi beberapa tipe: kapal pengangkut ikan, supervisor ship, kapal penangkap ikan dan kapal survey.

Kapal pengangkut ikan adalah kapal yang digunakan untuk membawa dan mengangkut ikan atau produksi laut dan dilengkapi dengan alat pendingin atau gudang dingin atau peralatan refrigerasi meliputi es dengan temperatur yang ditentukan[1]. Bersamaan dengan determinasi dari Kementrian Kelautan dan Perikanan nomor 11/MEN/2004. Kapal pengangkut ikan khususnya untuk mengangkut ikan, termasuk pendinginan, menyimpan dan membawa. Beberapa negara sudah mengaplikasikan konsep dari kapal penangkapikan, seperti Norway yang sudah mempunyai 109 kapal penangkap ikan dan 4 kapal pengangkut ikan sejak 1991. Konsep ini dibuat sebagai solusi dari kurang efisiennya kapal penangkap ikan yang menangkap ikan dan kembali ke darat untuk menjualnya. Hal ini terlihat kurang efisien karena menjadi 
pemborosan biaya operasional. Dengan konsep kapal pengangkut ikan, kapal penangkap ikan tidak perlu kembali lagi pelabuhan perikanan. Kapal pengangkut ikan digunakan untuk mengangkut hasil ikan dan akan kembali ke pelabuhan untuk dijual.

\section{B. Loading and Unloading System}

Loading and Unloading System didefinisikan sebagai permesinan bantu yang digunakan untuk proses bongkar muat material dari kapal ke kapal. Beberapa metode ini digunakan untuk memindahkan ikan dari satu kapal ke kapal lainnya, menggunakan metode sebagai berikut:[2][3]

1. Net-Lift; jaring digunakan untuk mengangkut ikan dimana jaring tersebut tersambung dengan crane, kekurangan dari metode ini adalah muatan ikan dapat jatuh pada saat jaring diangkat oleh crane.

2. Bucket - Winch and Chute; muatan ikan diangkat menggunakan bucket yang disambungkan dengan crane lalu dipindahkan menggunakan conveyor.

3. Elevator and Conveyor; menggunakan elevator untuk mengangkat muatna ikan dan menggunakan conveyor untuk memindahkan muatan ikan dari kapal. Metode ini adalah yang paling umum diaplikasikan.

\section{Bunkering System}

Bunkering adalah aktivitas untuk menssuplai kapal dengan bahan bakar, pelumas lubrikasi dan air yang mana umumnya dilakukan di pelabuhan. Namun terkadang bunkering juga dilakukan ditengah laut lepas [4].

Ship to Ship (STS) bunkering sudah mulai umum diaplikasikan. Dengan menggunakan kapal sebagai supplier dan kapal lainnya sebagai yang disupplai. Transfer dilakukan menggunakan hose sebagai media konektor antara 2 kapal. Pompa bunkering digunakan di kapal pensupplai untuk memompa fluida ke kapal lain menggunakan hose [4].

Pompa bunkering yang terletak di kapal pensupplai memindahkan bahan bakar dari tangki bahan bakar kapal pensupplai menuju tangki bahan bakar kapal lain menggunakan hose. Jumlah tangki yang dapat ditentukan untuk tangki bunkering bahan bakar dapat ditentukan dari jumlah tangki bahan bakar yang tersisa apabila sudah dikurangi dengan bahan bakar yang diperlukan untuk operasional Mianjaya 11, untuk mendapatkan nilainya dibutuhkan rumus [5].

$$
C=0,75 x P(\max ) x(S / d) x T
$$

dimana,

$$
\begin{array}{ll}
\mathrm{C} & =\text { Konsumsi bahan bakar }\left(\mathrm{m}^{3}\right) \\
\mathrm{P} & =\text { Engine Continous Rating }(\mathrm{HP}) \\
\mathrm{S} & =\text { Specific fuel oil consumption }(\mathrm{g} / \mathrm{kwh})
\end{array}
$$

\section{Adsorption System}

Sistem pendingin siklus adsorpsi hampir sama dengan silus pendingin kompresi. Perbedaannya terdapat pada komponen utama yang dipakai. Pada sistem pendingin siklus adsorpsi terdapat adsorber, pompa, generator kolektor yang menggantikan compressor. Sistem adsorbs menyerap uap tekanan rendah pada evaporator menjadi liquid penyerap. Oleh karena itu, absorber mempunyai fungsi sebagai pengganti refrigerant pada siklus pendingin kompresi uap [6].

Impelentasi pembuat es sistem adsorbs pada kapal ikan yang digerakan oleh gas buang dari motor diesel dianalisis oleh Wang, L.W et.al [7]. Pada paper ini, penelitian sebelumnya akan dijadikan pertimbangan pada saat pemilihan pasangan adsorpsi.

Wang, S.G \& Wang, R.Z [8] menganalisis contoh sistem adsorbsi di laboratorium untuk membuat flake ice. Pada paper ini penelitian yang sudah pernah dilakukan akan dijadikan pertimbangan pada saat merencanakan engineering drawing untuk proses instalasi sistem adsorbs pada Minajaya 11.

Pemilihan komponen refrigerasi berdasarkan kapasitas pendinginya $(\mathrm{Q})$ untuk setiap komponen kemudian memilih komponen yang sesuai dengan kapasitas pendinginnya yang dibutuhkan, metode ini dianalisis dan dipakai oleh Kong, X.Q, Wang, R.Z \& Huang, X.H [9]

\section{RENCANA KONVERSI}

\section{A. Rencana Konversi Secara Umum}

Rencana modifikasi secara umum untuk Minajaya 11 adalah untuk mengkonversi kapal Minajaya 11 dari kapal penangkap ikan menjadi kapal pengangkut ikan. Oleh karena itu terdapat perubahan dimensi dari Minajaya 11 seperti sarat air yang berubah. Gambar 1 dibawah ini menjelaskan rencana konversi secara umum.

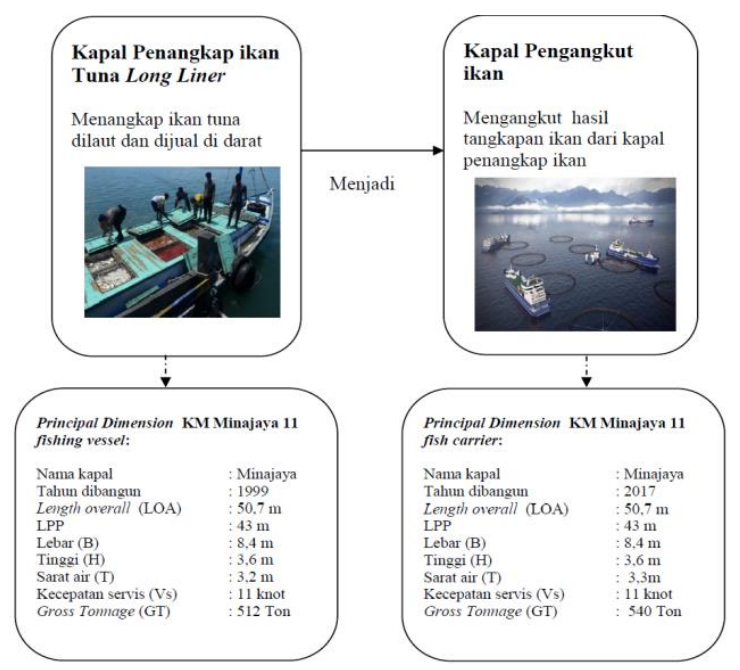

Gambar 1. Rencana Konversi Secara Umum

Gambar 1 menjelaskan perbedaan fungsi dari kapal Minajaya 11 yang awalnya berupa kapal penangkap ikan tuna long liner lalu tangkapan ikan tersebut akan dijual ke darat. Sedangkan, rencana konversi adalah untuk menkonversi kapal Minajaya 11 menjadi kapal pengangkut ikan, kapal pengangkut ikan mempunyai fungsi untuk mengangkut ikan dari kapal penangkap ikan di fishing ground. Oleh karena itu kapal penangkap ikan tidka perlu kembali ke darat apabila palkah ikannya penuh, kapal pengangkut ikan akan 
mendatangi kapal penangkap ikan dan membawa hasil tangkapan ikan dan akan meningkatkan efisiensi dari pola operasional. Perubahan tahun dibangun berubah dari 1999 menjadi 2017 karena Minajaya 11 dibuat pada tahun 1999 dan rencana proses konversi dilakukan pada tahun 2017. Terjadi perubahan sarat dari kapal Minajaya yang awalnya adalah 3,2 $\mathrm{m}$ menjadi $3,3 \mathrm{~m}$ karena penambahan komponen yang ditambahkan pada kapal Minajaya 11.

\section{B. Rencana Konversi Berdasarkan Pola Operasional}

Kapal Minajaya 11 yang awalnya adalah kapal tuna long liner yang memiliki pola operasional untuk mempersiapkan logistic untuk krew, logistic untuk menangkap ikan seperti es dan umpan, mempersiapkan peralatan memancing dan bahan bakar yang diperlukan untuk operasional pada saat tahap persiapan. Kapal penangkap ikan pun menuju fishing ground dan menangkap ikan dengan peralatan pancingnya. Pada saat palkah ikan sudah penuh atau logistik yang dibutuhkan krew sudah habis, kapal penangkap ikan akan kembali ke darat untuk menjual hasil tangkapannya.

Rencana konversi kapal Minajaya 11 menjadi kapal pengangkut ikan akan megubah skenario operasional dari kapal sebelumnya. Kapal Minajaya 11 tidak akan lagi menangkap ikan namun untuk mengangkut ikan dari kapal penangkap ikan yang berada pada fishing grounds. Karena Minajaya 11 memiliki palkah ikan, tangka bahan bakar, ruang logistik krew, ruang akomodasi krew yang besar, maka kelebihan ini akan dimanfaatkan tidak hanya untuk mengangkut ikan saja namun juga digunakan untuk menyediakan logistik untuk kapal penangkap ikan yang berada pada fishing ground yang berupa;

1. Bahan bakar yang diperlukan untuk operasional kapal penangkap ikan.

2. Logistik untuk kapal penangkap ikan seperti makanan dan minuman

3. Keperluan operasional yang dibutuhkan kapal penangkap ikan seperti es, umpan.

4. Pertukaran krew dari kapal penangkap ikan ke kapal pengangkut ikan

5. Mengangkut hasil tangkapan ikan dari kapal penangnkap ikan ke kapal pengangkut ikan.

Oleh karena itu Kapal Minajaya 11 sebagai kapal pengangkut ikan akan berlayar menuju fishing ground dimana kapal penangkap ikan terletak. Pada saat kapal Minajaya 11 sampai di fishing ground 1, maka kapal Minajaya 11 akan menghampiri kapal penangkap ikan dengan kapasitas 40-50 GT untuk melakukan transaksi muatan dan logistik seperti yang sudha dijelaskan di atas. Setelah proses transaksi selesai, kapal Minajaya 11 akan menuju ke fishing ground 2 dan melakukan proses yang sama. Kapal Minajaya 11 akan mengulang proses transaksi yang sama sampai ke fishing ground 4. Lalu Minajaya 11 akan berlayar kembali ke fishing ground sebelumnya (FG 3,2,1) untuk melakukan transaksi lagi sampai ke fishing grounds 1. Setelah itu proses pelayaran kembali ke fishing grounds 4 lagi dengan melewati FG 2 dan 3. Setelah itu Minajaya 11 akan kembali ke pelabuhan perikanan di Bitung, Sulawesi Utara. Teritori operational dengan memakai WPP 716 di Indonesia dengan pelabuhan perikanan Bitung sebagai homebase. Scenario tersebut diilustrasikan pada Gambar 2 dibawah ini.

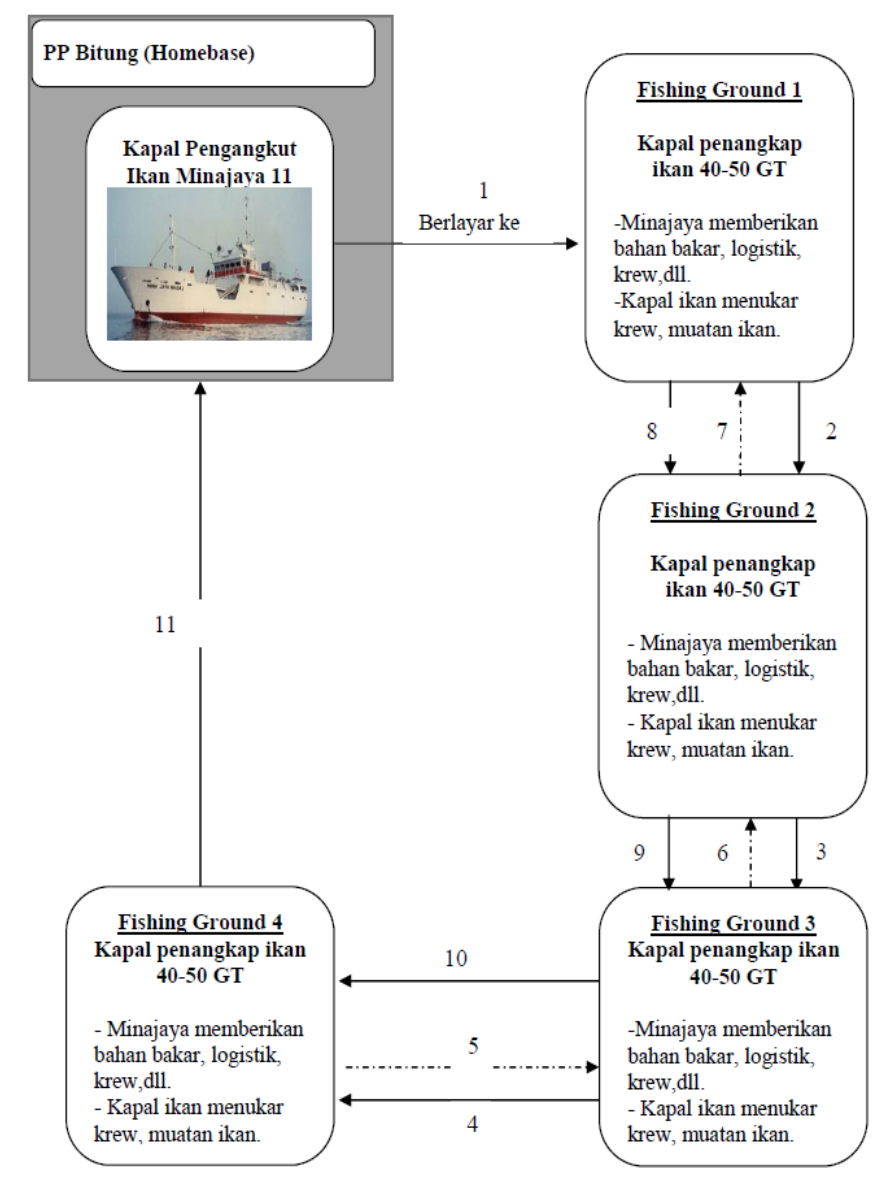

Gambar 2. Rencana Konversi Pola Operasional

\section{Analisis Konversi Berdasarkan Sistem Pendukung}

Perubahan sistem pada kapal Minajaya 11 mempunyai tujuan untuk meningkatan efisiensi teknis untuk mengoperasikan Minajaya 11 sebagai kapal pengangkut ikan. Dengan sistem kapal Minajaya 11 yang sudah ada di kapal sejak kapal tersebut dibangun, perubahan harus dilakukan guna untuk meningkatkan efisiensi teknis. Perencanaan penambahan-penambahan sistem berdasarkan dari regulasi standart. Menggunakan standart DNV-GL unutk konversi kapal, penambahan sistem harus digambar pada aransemen dan engineering drawing termasuk proses pelepasan alat pancing Minajaya, penambahan sistem bunkering, penambahan sistem bongkar muat dan memperbaharui fire and safety plan, memperbaharui general arrangement dengan konfigurasi yang baru dan memperbaharui beban generator menggunakan konfigurasi baru dengan tambahan komponen yang dilakukan pada proses konversi. Gambar 3 menjelaskan diagram rencana penambahan atua perubahan sistem yang akan dilakukan ada kapal Minajaya 11. 


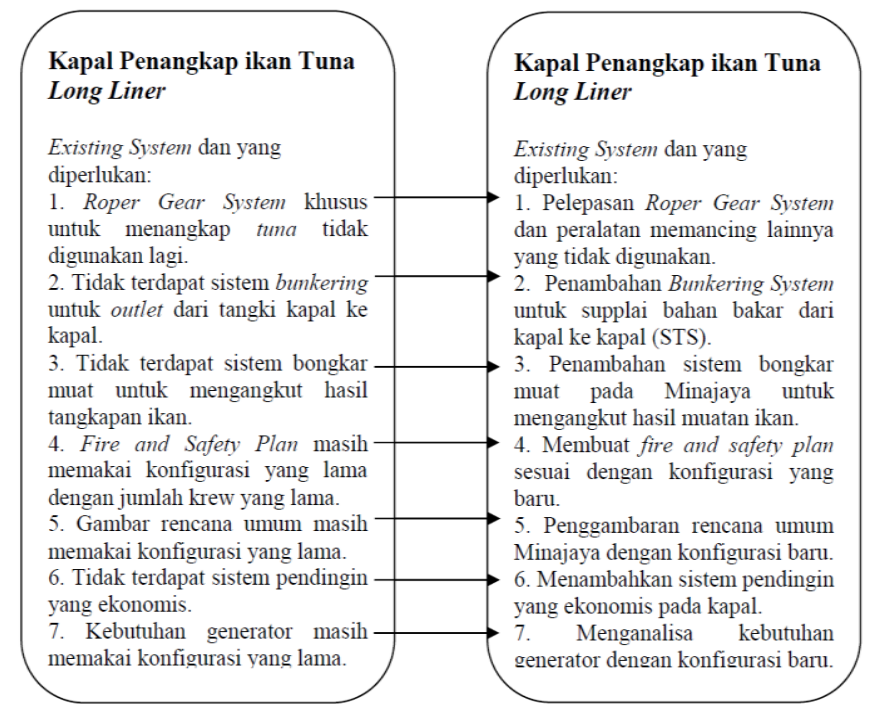

Gambar 3. Rencana Konversi Berdasarkan Sistem

\section{HASIL DAN ANALISIS}

\section{A. Bunkering System}

Tangki bahan bakar Minajaya 11 dibagi menjadi 2 bagian, dimana terdapat beberapa tangki bahan bakar yang digunakan untuk keperluan operasional kapal Minajaya 11, dan beberapa tangki yang tersisa untuk keperluan penyupplai bahan bakar ke kapal penangkap ikan di fishing ground. Penambahan bypass pada sistem perpipaan bunkering Minajaya 11 ditambahkan agar pompa gear dapat memompa fluida bahan bakar masuk dan keluar bahan bakar. Sistem bunkering ini dilengkapi dengan mass flowmeter pada sisi outlet yang berfungsi untuk mengukur bahan bakar yang keluar atau untuk mengetahui jumlah bahan bakar yang sudah di transfer, hal ini diperlukan untuk mempermudah proses transaksi dalam proses penjualan. Proses bunkering memerlukan waktu sekitar 20 menit untuk memindahkan bahan bakar dari tangki bahan bakar pada kapal Minajaya 11 menuju tangki bahan bakar kapal penangkap ikan, menggunakan persamaan 1 untuk menghitung kebutuhan bahan bakar Minajaya lalu sisanya akan dipergunakan untuk mensupplai kebutuhan bahan bakar kapal penangkap ikan. Rangkuman dari perhitungan ditunjukkan pada tabel 1 dan engineering drawing dari sistem bunkering diilustrasikan pada Gambar 4.

Tabel 1.

Tangki Bahan Bakar Minajaya 11 Untuk Bunkering

\begin{tabular}{|c|c|c|c|}
\hline Tipe Tangki & $\begin{array}{c}\begin{array}{c}\text { Keperluan } \\
\text { bahan bakar } \\
\left(\mathbf{m}^{3}\right)\end{array} \\
\end{array}$ & $\begin{array}{c}\text { Lama } \\
\text { Pelayaran }\end{array}$ & Tangki yang dipilih \\
\hline $\begin{array}{l}\text { Operasional } \\
\text { Minajaya }\end{array}$ & 144,69 & $\begin{array}{c}1 \text { bulan atau } \\
\text { minggu }\end{array}$ & $\begin{array}{c}\text {-No.3 FO Tank (p,s) } \\
\text {-No.4 FO Tank } \\
\text { (center) } \\
\text {-No.5 FO Tank (p,s) } \\
\text {-Stern FO tank (p,s) } \\
\text {-Service FO tank }\end{array}$ \\
\hline $\begin{array}{l}\text { Kebutuhan } \\
\text { Supplai }\end{array}$ & $4-8 \mathrm{~m}^{3}$ per kapal & & $\begin{array}{l}\text {-Deep FO Tank (p,s) } \\
\text {-No.2 FO Tank (p,s) } \\
\text {-No.1 FO Tank (p,s) }\end{array}$ \\
\hline
\end{tabular}

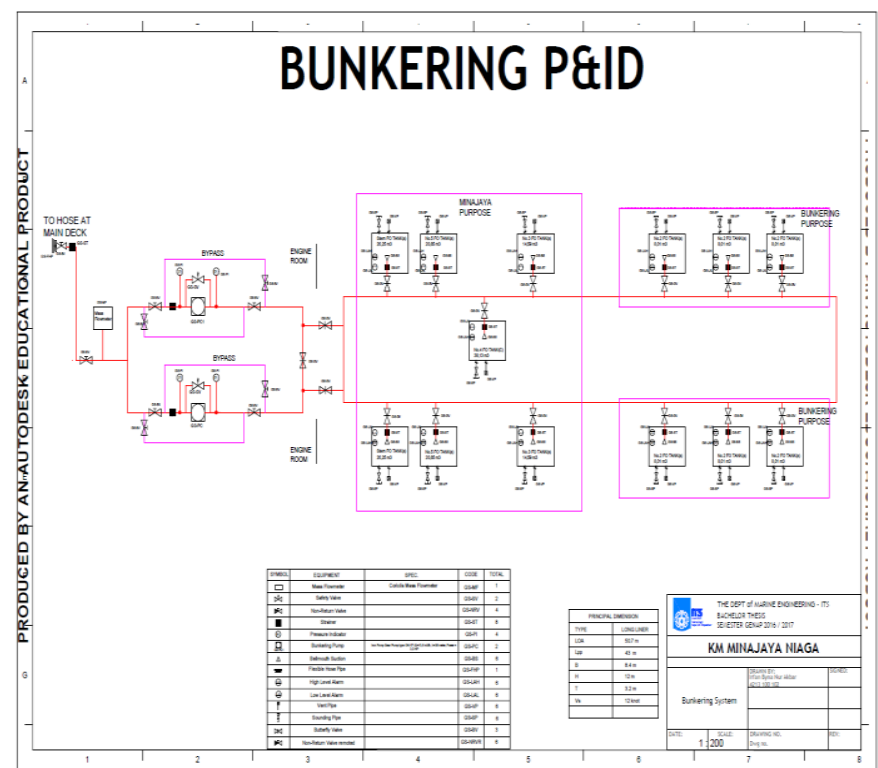

Gambar 4. Rencana Konversi Berdasarkan Sistem

\section{B. Loading and Unloading System}

Sistem bongkar muat merupakan sistem yang berperan penting pada pengoperasian Minajaya 11 sebagai kapal pengangkut ikan. Metode menggunakan conveyor digunakan untuk proses bongkar muat. Scenario yang akan digunakan adalah:

\section{1) Waktu Bongkar Muat}

Desain dari bongkar muat Minajaya 11 menggunakan provision crane dan conveyor untuk proses bongkar muat ikan dari kapal penangkap ikan ke kapal pengangkut ikan Minajaya 11. Berdasarkan dari spesifikasi crane, working speed dari crane akan digunakan untuk menentukan lamanya waktu yang diperlukan untuk mengangkat conveyor. Selain itu, spesifikasi konveyor pada bagian kecepatan motor digunakan untuk menentukan lamanya waktu konveyor dapat memindahkan kargo ikan dari kapal penangkap ikan. Lama waktu dari bongkar muat dipisah kedalam beberapa kategori dan ditunjukkan pada Tabel 2.

2) Kebutuhan Transaksi

Untuk membuat efisiensi teknis pada sistem bongkar muat dan buat keperluan yang ekonomis. Sistem bongkar muat dilengkapi dengan alat pengukur untuk menentukan berat ikan yang sudah dipindahkan. Alat pengukur berat ini diinstal di konveyor sehingga konveyor dapat mengetahui berat dari ikan yang sudah dipindahkan dari kapal penangkap ikan menuju ke kapal pengangkut ikan.

Tabel 2.

Durasi Waktu Bongkar Muat

\begin{tabular}{cccc}
\hline \hline Tipe pekerjaan & $\begin{array}{c}\text { Kecepatan } \\
\text { Crane }\left(\mathbf{m}^{2} / \mathbf{s}\right)\end{array}$ & $\begin{array}{c}\text { Kecepatan } \\
\text { konveyor }\left(\mathbf{m}^{2} / \mathbf{s}\right)\end{array}$ & Waktu (s) \\
\hline $\begin{array}{c}\text { Mengangkat } \\
\text { conveyor } \\
\text { kenggunakan } \\
\text { crane }(1)\end{array}$ & 0,25 & & 40 \\
$\begin{array}{c}\text { Bongkar muat } \\
\text { menggunakan } \\
\text { conveyor }\end{array}$ & - & 0,33 & \\
Mengangkat \\
konveyor \\
kembali
\end{tabular}




\section{Adsorption System}

Sistem adsorbsi adalah sistem alternative yang direncanakan akan diaplikasikan di Minajaya 11 dari permasalahan ekonomis. Sistem adsorbs dapat mengkonversi panas yang terdapat pada gas buang dari main engine untuk memproduksi sekitar $500 \mathrm{~kg}$ es flake setiap harinya apabila motor utama dioperasikan 24 jam. Komponen yang digunakan adalah penukar panas untuk mengkonversi panas dari gas buang untuk memproduksi air panas.

Air panas yang nantinya digunakan untuk memisahkan pasangan adsorpsi, pasangan adsorpsi terdiri dari methanol sebagai adsorben dan karbon aktif sebagai adsorbat yang akan terpisah karena temperature tinggi dari air yang berasal dari penukar panas. Pasangan adsorben dan adsobat terletak pada generator kolektor. Evaporator digunakan untuk memproduksi es, sistem dari adsorpsi ini diilustrasikan pada Gambar 5.

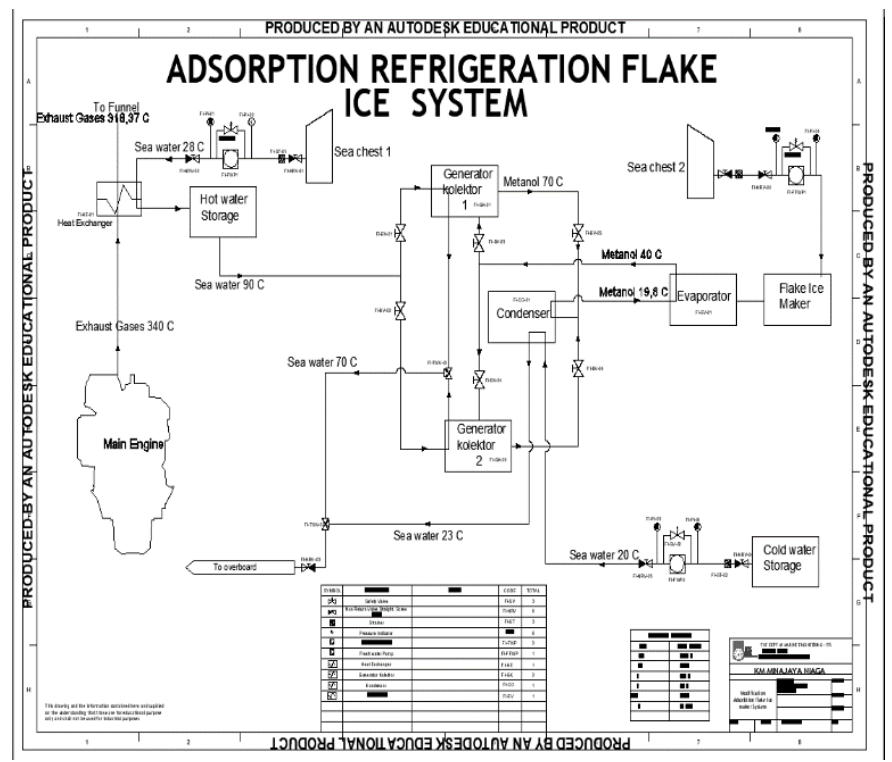

Gambar 5. Engineering Drawing Sistem Adsorpsi

\section{Kalkulasi Beban Generator}

Beberapa sistem dan perubahan aransemen yang terjadi di Minajaya 11 berdasarkan rencana konversi. Setelah proses kalkulasi dan pemilihan komponen, beban generator dengan komponen yang baru dapat dihitung. Semua komponen yang ditambahkan sesuai dengan modifikasi sistem yang dilakukan. Beban generator pada Minajaya 11 dilakukan dengan menjumlahkan kebutuhan daya listrik yang diperlukan untuk semua komponen dan permesinan. Semua daya listrik didapatkan dari komponen, penerangan, stop kontak, dll. Semuanya akan dijumlahkan dan akan didapatkan beban total pada setiap kondisi. Setelah mendapatkan beban total di empat kondisi berbeda, didapatkan beban generator diantara $65-85 \%$. Oleh karena itu penambahan komponen pada Minajaya dengan menggunkan generator yang sudah ada dapat digunakan dan sesuai dengan standar kelas. Rangkuman dari perhitungan beban generator ditunjukkan pada Tabel 3 dibawah ini.
Tabel 3

Beban Generator Kapal Minajaya 11 Setelah Konversi

\begin{tabular}{llllll}
\hline \hline $\begin{array}{l}\text { Tipe } \\
\text { Generator }\end{array}$ & $\begin{array}{l}\text { Jumla } \\
\text { h }\end{array}$ & $\begin{array}{l}\text { Sail } \\
(\%)\end{array}$ & $\begin{array}{l}\text { Manuve } \\
\boldsymbol{r}(\boldsymbol{\%})\end{array}$ & $\begin{array}{l}\text { Loading/Unl } \\
\text { oading }(\boldsymbol{\%})\end{array}$ & $\begin{array}{l}\text { Pelabuhan } \\
(\boldsymbol{\%})\end{array}$ \\
\hline LE ROY & & & & & \\
SOMER LSA & 2 & 77,2 & 77,7 & 80,1 & 72,9 \\
M47 1 L9 (256 & & & & & \\
kW) & & & & & \\
\hline \hline
\end{tabular}

\section{E. Rencana Umum}

Seluruh komponen, peralatan dan desain yang telah dipilih akan digambarkan dan akan membuat rencana umum. Aransemen dari peralatan, tangki dan permesinan akan digambarkan pada layout. Peralatan memancing tidak akan digunakan lagi pada Minajaya 11 dan akan dihapus dari rencana umum. Perubahan rencana umum juga terjadi disebabkan karena perubahan jumlah krew. Semua penambahan komponen yang ditambahkan pada Minajaya 11 akan merubah rencana umum dari kapal Minajaya 11, untuk membuktikkan bahwa rencana umum masih cukup untuk penambahan komponen, general arrangement akan digambarkan.

Perubahan pada Rencana umum akan digambarkan pada Gambar 6, dimana pada rencana umum untuk warna ungu adalah komponen yang ditambahkan atau ruangan yang ditambahkan pada kapal Minajaya 11 sebagai kapal pengangkut ikan.
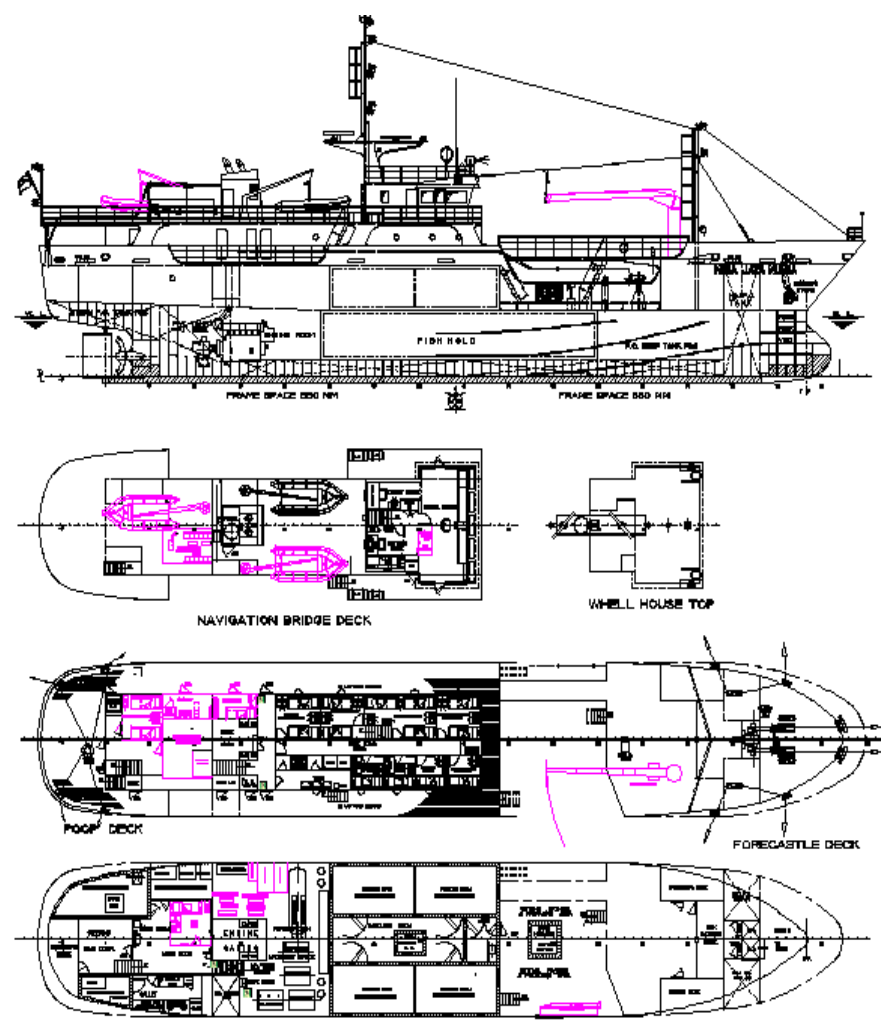

MAIN DEET

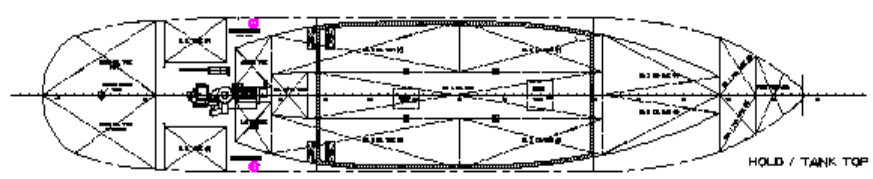

Gambar 6. Rencana Umum Kapal Pengangkut Ikan Minajaya 11 


\section{KESIMPULAN/RINGKASAN}

Berdasarkan kalkulasi, desain modifikasi dan drawing yang dilakukan, didapatkan kesimpulan yang dijelaskan dibawah ini:

1. Untuk Mengubah kapal penangkap ikan Minajaya 11 menjadi kapal pengangkut ikan, langkah-langkah perhitungan dan penambahan sistem telah dilakukan yaitu:

a. Sistem Bongkar muat dihitung berdasarkan regulasi dari FAO mengenai bongkar muat ikan, dengan menambahkan provision crane dan conveyor

b. Sistem bunkering dihitung dari standar FAO mengenai operasional kapal ikan, dengan hasil total durasi bunkering selama 20 menit

c. Sistem pendingin adsorpsi dihitung berdasarkan penelitian sebelumnya mengenai pembuatan es dari sistem adsorpsi, dengan kemampuan memproduksi es sebanyak $500 \mathrm{~kg}$ setiap harinya

d. Analisis perhitungan beban generator dihitung berdasarkan regulasi dari kelas BKI, didapatkan kapal Minajaya 11 tetap dapat menggunakan generator existing karena load factor yang berkisar $65-85 \%$

2. Untuk mengubah kapal penangkap ikan Minajaya 11 menjadi kapal pengangkut ikan, langkah-langkah penggambaran sistem telah dilakukan yaitu:

a. Fire and Safety Plan diperbaharui berdasarkan standar dari SOLAS mengenai keselamatan kapal di laut

b. Sistem bongkar muat didesain ulang mengikuti standar dari FAO mengenai bongkar muat ikan dan sudah sesuai dengan standar.

c. Sistem bunkering didesain ulang menggunakan regulasi dari GL dan BKI mengenai sistem perpipaan bahan bakar dan sudah sesuai dengan standar.

d. Sistem adsorpsi didesain ulang dengan menggunakan regulasi dari GL dan BKI mengenai instalasi sistem pendingin pada kapal dan sudah sesuai dengan standar.

e. Rencana umum diperbaharui berdasarkan standar dari Marine labour convection 2006 dan sudah sesuai dengan standar.

\section{DAFTAR PUSTAKA}

FAO, "Regional Compendium of Fisheris Legislation," Linear Networks Syst., vol. 1, pp. 417-418, 1993.

[2] R. Davis, "Fish Handling Systems, a List of Equipment Used From Sea to Boat to Wharf," 1974.

[3] FAO, "Freezing and Refrigerated Storage in Fisheries," pp. 30-35, 1994

[4] et al Volkering, Bunkering at Sea. Rotterdam, 2015.

[5] J. Dremiere, P.Y \& Prado, Petunjuk Praktis Bagi Nelayan. Caracalla rome, 1990.

[6] J. . Merrit, Refrigeration on Fishing Vessels. England: Farnham fishing news book 1td, 1988.

[7] L. . et al. Wang, "Adsorption Ice Makers for Fishing Boats Driven by The Exhaust Heat from Diesel Engine: Choice of Adsorption Pair," Inst. Refrig. Cryog.

[8] R. . Wang, S.G \& Wang, "Recent Development of Refrigeration Technology in Fishing Vessels," Inst. Refrig. Cryog.

[9] X. . Kong, X.Q, Wang, R.Z \& Huang, "Energy Efficiency and Economic Feasibility of CCHP Driven by Stirling Engine," Inst. Refrig. Cryog., 2003. 